\title{
HUBUNGAN POWER OTOT TUNGKAI DENGAN KECEPATAN LARI JARAK PENDEK
}

\section{RELATIONSHIP OF LIMB MUSCLE POWER AND SHORT DISTANCE RUNNING SPEED}

\author{
${ }^{1 *}$ Ahmad Lamusu, ${ }^{2}$ Sarjan Mile, ${ }^{3}$ Zulkifli Lamusu \\ $1^{*, 2,3}$ pendidikan Jasmani Kesehatan dan Rekreasi, Fakultas Olahraga dan Kesehatan Universitas Negeri Gorontalo \\ Kontak koresponden: ahmadlamusu2020@gmail.com
}

\begin{abstract}
ABSTRAK
Penelitian ini bertujuan untuk mengetahui hubungan power otot tungkai dengan kecepatan lari jarak pendek pada mahasiswa Pendidikan Jasmani, Kesehatan dan Rekreasi (PJKR) Fakultas Olahraga dan Kesehatan Universitas Negeri Gorontalo. Metode penelitian yang digunakan adalah metode penelitian kuantitatif yang bersifat korelasi. Desain terdiri atas 2 variabel penelitian yaitu Variabel X (power otot tungkai) dengan Variabel Y (kecepatan lari jarak pendek). Adapun sampel dalam penelitian yang ditetapkan adalah sebanyak 20 mahasiswa Pendidikan Jasmani, Kesehatan dan Rekreasi (PJKR) Fakultas Olahraga dan Kesehatan Universitas Negeri Gorontalo yang diambil secara Purfosive Sampling. Uji statistik yang digunakan untuk menguji hipotesis penelitian ini adalah uji korelasi. Hasilnya ada hubungan variabel $\mathrm{X}$ dengan variabel $\mathrm{Y}$ adalah signifikan. Dari data tersebut dapat menjawab hipotesis bahwa ada Hubungan antara power otot tungkai dengan kecepatan lari jarak pendek pada mahasiswa Pendidikan Jasmani, Kesehatan dan Rekreasi (PJKR) Fakultas Olahraga dan Kesehatan Universitas Negeri Gorontalo.
\end{abstract}

Kata Kunci: power; otot tungkai; kecepatan lari

\section{ABSTRACT}

This study aims to determine the relationship between leg muscle power and short-distance running speed for students of Physical Education, Health and Recreation (PJKR) Faculty of Sports and Health, State University of Gorontalo. The research method used is a quantitative research method that is correlational. The design consisted of 2 research variables, namely Variable X (leg muscle power) and Variable Y (speed of short distance running). The sample in the research that was determined was as many as 20 students of Physical Education, Health and Recreation (PJKR) Faculty of Sport and Health, State University of Gorontalo taken by purfosive sampling. The statistical test used to test the hypothesis of this research is the correlation test. The result is that there is a significant relationship between the $X$ variable and the $Y$ variable. From these data, it is possible to answer the hypothesis that there is a relationship between leg muscle power and short-distance running speed in Physical Education, Health and Recreation (PJKR) students, Faculty of Sport and Health, State University of Gorontalo.

Keywords: power; leg muscles; running speed 


\section{Pendahuluan}

Dewasa ini pembinaan dibidang keolahragaan semakin pesat dan memperlihatkan gejala yang amat kompleks, karena kegiatan tersebut tidak berdiri sendiri melainkan berinteraksi langsung dengan berbagai faktor seperti ekonomi, politik, sosial dan budaya. Upaya untuk mencapai hasil atau prestasi dalam kegiatan keolahragaan sangat membutuhkan penguasaan keterampilan yang tinggi (Mirhan, 2016) (Hardinoto et al., 2017). Karena penguasaan keterampilan yang tinggi merupakan kunci untuk membuka kearah kemajuan dalam prestasi olahraga, hal tersebut hanya dapat dicapai melalui kegiatan belajar dan berlatih.

Cabang olahraga atletik sesungguhnya merupakan bagian yang tak dapat dipisahkan dari gerakan olahraga Indonesia yang bertujuan untuk membentuk jasmani dan rohani yang sehat dan berkepribadian luhur (Faizah \& Herdyanto, 2019). Atletik merupakan salah satu unsur yang berpengaruh dalam membangun mental spiritual dan fisik mahasiswa dalam rangka membentuk mahasiswa seutuhnya yang berfalsafah Pancasila dan Undang-Undang Dasar 1945 (Ramadhan et al., 2020). Karena itu atletik merupakan wahana edukatif yang berusaha menanamkan semangat keolahragaan yang diharapkan dan mampu mengangkat derajat mahasiswa menjadi insan yang berwatak sportif, berbudi luhur, dan yang paling utama adalah sehat dan bugar (Iskandar, 2017). Kesadaran dan keinginan mahasiswa untuk mewujudkan kesehatan jiwa dan raganya yang tangguh dan berprestasi melalui aktivitas olahraga atletik mudah terlaksana.

Pelaksanaan cabang olahraga atletik terutama melakukan gerakan nomor lari banyak dipengaruhi oleh berbagai faktor, antara lain adalah kemampuan kondisi fisik (physical ability) (Gunadi \& Kuncoro, 2020). Kemampuan kondisi fisik tidak hanya ditentukan oleh salah satu faktor saja tetapi dibentuk oleh berbagai faktor atau komponen (Putra \& Ita, 2019). Komponen yang dianggap penting dan diperlukan untuk menilai kemampuan fisik adalah power otot, karena power otot merupakan faktor yang paling utama dalam meningkatkan kondisi fisik secara keseluruhan dan juga merupakan daya penggerak setiap aktivitas fisik terutama dalam cabang olahraga yang membutuhkan gerakan-gerakan eksplosif (Pembayun et al., 2018).

Latihan fisik khususnya power otot sangat penting artinya dalam pencapaian prestasi yang maksimal (Kuswahyudi \& Nurdin, 2017). Oleh karena power otot hanya dapat dicapai melalui latihan yang teratur dan terarah serta terprogram dengan baik sesuai dengan cabang olahraga yang ditekuni. Hal ini dapat diasumsikan bahwa untuk mencapai kemampuan melakukan lari perlu diberikan bentuk-bentuk latihan power otot tungkai yang lebih akurat.

Peningkatan olahraga prestasi merupakan suatu hal yang selalu di permasalahkan dan tidak habis-habisnya diperbincangkan sepanjang masa, bahkan diperbincangkan pula selama olahraga itu dikenal sebagai kebutuhan hidup manusia. Prestasi olahraga bersifat dinamis progresif, setiap fase waktu tertentu berubah serta cenderung maju dan meningkat. Peningkatan prestasi olahraga tidak lepas dari peranan pendekatan ilmiah. Perkembangan ilmu pengetahuan dan teknologi turut berpengaruh dalam meningkatkan prestasi dibidang keolahragaan. Peningkatan ilmu pengetahuan dan teknologi tersebut turut berpengaruh bagi peningkatan prestasi olahraga terutama pada cabang olahraga atletik khususnya nomor lari jarak pendek. Jadi dalam pencapaian prestasi olahraga lari jarak pendek merupakan usaha yang benar-benar 
diperhatikan secara matang melalui proses pembinaan dan pembibitan sejak dini. Oleh karena itu dengan pencapaian prestasi olahraga, seseorang yang ingin mencapai prestasi secara optimal perlu memiliki empat macam kelengkapan dalam pembinaan prestasi olahraga yaitu meliputi: pengembangan fisik, pengembangan teknik, pengembangan mental, dan kematangan juara.

Atletik adalah salah satu cabang olahraga yang tertua yang dilakukan oleh manusia sejak jaman Yunani Kuno sampai dewasa ini. Dalam materi pelajaran atletik yang dipelajari adalah gerakan dasar manusia di dalam kehidupan sehari-hari, yaitu berjalan, berlari, melompat dan melempar. Selain itu dalam kejuaraan atletik ada beberapa nomor yang diperlombakan diantaranya adalah jalan cepat, nomor lari, nomor lompat dan nomor lempar. Khusus untuk nomor lari yang diperlombakan baik yang bersifat nasional maupun internasional terdiri dari nomor lari jarak pendek, jarak menengah dan lari jarak jauh. Selain penguasaan teknik - teknik di atas, kekuatan otot tungkai juga sangat penting menjadi perhatian dalam membina cabang olahraga atletik khususnya nomor lari jarak pendek. Karena kekuatan atau power otot tungkai mempunyai andil yang tidak kalah pentingnya dalam pencapaian prestasi dalam nomor lari jarak pendek. Misalnya saja dengan power atau kekuatan dan daya ledak otot tungkai yang akan menghasilkan kecepatan yang maksimal dalam nomor lari. Kekuatan otot tungkai seseorang dapat mempengaruhi setiap aktivitasnya dalam olahraga, karena kekuatan otot tungkai yang dimiliki biasanya dihubungkan dengan kemampuan atau kekuatan fisik yang dimilikinya.

Sehubungan dengan tuntutan teknik dasar dalam cabang olahraga atletik khususnya nomor lari jarak pendek (Sprint) maka terlihat dengan jelas bahwa kekuatan otot tungkai sangat dibutuhkan, terutama dalam gerakan berlari, serta untuk mendapatkan hasil yang baik dan terarah diantaranya adalah kekuatan otot tungkai.

Dalam cabang olahraga atletik nomor lari jarak pendek sangat dibutuhkan teknik dan kecepatan berlari. Teknik berlari merupakan unsur gerakan yang dapat menunjang pelari untuk mencapai kecepatan maksimal. Salah satu elemen kondisi fisik yang sangat penting dalam lari jarak pendek adalah kecepatan. Kecepatan merupakan kemampuan untuk menyelesaikan suatu jarak tertentu dengan cepat. Kecepatan sangat difokuskan dalam lari jarak pendek yaitu hasil kontraksi otot yang kuat dan cepat dari tiap otot diubah menjadi gerakan yang sangat halus sehingga menciptakan gerakan atau kecepatan tinggi. Kecepatan seorang pelari dihasilkan oleh hubungan optimal antara panjang langkah dan frekuensi langkah (Syarifuddin, 2012:24).

Lari jarak pendek memerlukan kekuatan dan daya ledak otot tungkai agar dapat memberikan kecepatan serta waktu yang cepat serta memperoleh hasil yang maksimal, karena saat berlari otot-otot yang berkontraksi atau otot-otot yang diperlukan adalah otot-otot yang terdapat pada bagian tungkai.

Power otot atau daya ledak otot merupakan salah satu komponen yang penting dalam kegiatan olahraga, karena dengan power atau daya ledak kemampuan seseorang memukul, melompat, berlari dapat diukur kemam. Power atau daya ledak juga dapat diartikan sebagai kemampuan untuk meraih suatu kekuatan setinggi mungkin dalam waktu yang singkat. Menurut Widiastuti (2015:16) bahwa power atau daya ledak merupakan gabungan antara kekuatan dan kecepatan atau pengerahan otot maksimum dengan kecepatan maksimum atau bisa dikatakan 
bahwa power atau daya ledak adalah kemampuan kerja otot dalam satuan waktu. Selaras dengan hal ini Ismaryati (2006) menjelaskan bahwa power atau daya ledak otot menyangkut kekuatan dan kecepatan kontraksi otot yang dinamis dan eksplosif serta melibatkan pengeluaran kekuatan otot yang maksimal dalam waktu yang secepat cepatnya. Hal yang sama dikemukakan oleh Sajoto (1988) bahwa daya ledak otot (muscular power) adalah kemampuan seorang untuk melakukan kekuatan maksimum, dengan usaha yang dikerahkan dalam waktu yang sependekpendeknya. Power adalah hasil dari dua kemampuan yaitu kecepatan maksimal dan kekuatan maksimal dalam waktu yang sesingkat mungkin. Dengan kata lain bahwa setiap gerakan tubuh dalam olahraga pada hakikatnya disebabkan berkontraksinya otot-otot rangka untuk mengatasi beban atau hambatan berupa berat tubuh sendiri seperti gerakan melompat yang melibatkan komponen dari otot tungkai (Ayu Widi Muchlisa, 2017:14).

Berbagai cabang olahraga memerlukan power otot atau daya ledak otot tungkai dalam penampilannya, terutama cabang-cabang olahraga yang membutuhkan kekuatan dan kecepatan dalam bereaksi, sebagai contoh cabang olahraga atletik, hampir semua nomor dalam cabang ini memerlukan daya ledak, mulai dari nomor lari, lompat maupun lempar dan berbagai cabang olahraga permainan (Ismadraga \& Lumintuarso, 2015). Power otot tungkai sangat diperlukan terutama pada saat melakukan gerakan- gerakan yang melibatkan kerja otot tungkai yang dikerahkan secara maksimal dalam waktu yang singkat seperti pada nomor lari jarak pendek.

Cabang olahraga atletik di dalamnya terdapat gerakan lari, melompat, dan melempar yang melibatkan kerja otot tungkai (Jarver, 2014). Agar bisa mempelajari teknik dasar pada nomor lari jarak pendek dengan mudah maka seseorang harus memiliki power otot tungkai atau daya ledak otot tungkai yang baik. Prestasi bergantung pada tenaga otot tungkai dan latihan eksplosifitas dapat memperbaiki kecepatan, pengembangan tenaga dan keduanya itu sangat perlu bagi prestasi yang baik.

Lari jarak pendek adalah salah satu nomor atletik dengan mengandalkan kekuatan otot kaki (Henjilito, 2017). Kecepatan dalam lari cepat (sprint) adalah hasil dari kontraksi yang kuat dan cepat dari otot-otot yang dirubah mejadi gerakan yang halus, lancar, dan efisien dibutuhkan bagi berlari dengan kecepatan tinggi (Dwi, 2020). Disamping itu juga, metode latihan yang baik untuk meningkatkan prestasi lari cepat (sprint) adalah latihan yang mampu meningkatkan biomotorik lainnya seperti kekuatan, fleksibilitas, koordinasi dan daya tahan khusus yang menyumbang kesuksesan dalam lari cepat (Widiastuti \& Pratiwi, 2017).

Lari jarak pendek pada dasarnya adalah gerak seluruh tubuh ke depan secepat mungkin yang dihasilkan oleh gerakan dari langkah-langkah kaki dalam menempuh jarak 100 meter (Bahagia, 2012). Kecepatan lari atlet tergantung dari dua faktor yang mempengaruhi, yaitu : 1) Panjang langkah adalah jarak yang ditempuh oleh setiap langkah yang dilakukan. Panjang setiap langkah yang dilakukan oleh seseorang pelari dapat dianggap sebagai jumlah dari ketiga jarang yang berbeda. (a) Jarak tinggal landas (take off distance) adalah jarak horizontal ketika pusat gravitasi menghadap ke ujung jari kaki yang tinggal landas pada saat kaki tersebut meninggalkan tanah, (b) Jarak terabang (flight distance) adalah jarak horizontal ketika pusat gravitasi berjalan pada saat pelari ada di udara, (c) Jarak pedaratan (landing distance) adalah jarak horizontal 
ketika ujung kaki yang ada di depan menghadap ke pusat gravitasi pada saat pelari mendarat; 2) Frekuensi langkah adalah jumlah langkah yang diambil pada suatu waktu tertentu (yang juga disebut sebagai irama langkah atau kecepatan langkah) (Muller \& Ritzdorf, 2000). Jumlah langkah yang dilakukan oleh atlet dalam sutau waktu tertentu ditentukan oleh berapa waktu yang diperlukan untuk menyelesaikan satu langkah, semakin lama waktu yang diperlukan maka semaki sedikit langkah yang dapat dilakukan oleh atlet dalam suatu waktu tertentu, dan sebaliknya.

\section{Metode}

Metode yang digunakan dalam penelitian ini adalah metode korelasional dengan menggunakan pendekatan kuantitatif. Penelitian ini dilakukan di lapangan olahraga Kampus 3 Universitas negeri Gorontalo yang populasinya berjumlah 37 mahasiswa kemudian sampelnya diambil dari mahasiswa Pendidikan Jasmani, Kesehatan dan Rekreasi (PJKR) Fakultas Olahraga dan Kesehatan Universitas Negeri Gorontalo yang berjumlah 20 orang menggunakan teknik Purfosive Sampling dengan kriteria mahasiswa putra, mau mengikuti tes secara sukarela, dan bukam merupakan atlet lari jarak pendek. Instrumen penelitian menggunakan Leg Dynamometer, pengujian tes dan pengukuran kecepatan lari 100 meter, adapun data pengambilan hipotesis dengan menggunakan rumus product moment.

\section{Hasil}

Dalam penelitian ini, data yang dimaksud adalah data yang diperoleh dengan menggunakan metode korelasional dengan menggunakan pendekatan kuantitatif yakni mendeskripsikan mengenai hubungan power otot tungkai dengan kecepatan lari jarak pendek pada mahasiswa Pendidikan Jasmani Olahraga Kesehatan Dan Rekreasi (PJKR) Fakultas Olahraga dan Kesehatan Universitas Negeri Gorontalo. Data dalam penelitian ini terdiri dari dua jenis tes, yaitu: (1) Mengukur power otot tungkai menggunakan Leg Dynamometer, (2) Tes melakukan lari jarak pendek menggunakan Stop Watch.

Tabel 1, Rangkuman Hasil Penelitian Power Otot Tungkai dan Kecepatan Lari Jarak Pendek

\begin{tabular}{ccc}
\hline Subjek & $\begin{array}{c}\text { Power Otot } \\
\text { Tungkai }\end{array}$ & $\begin{array}{c}\text { Lari 100 Meter } \\
(t \text { score })\end{array}$ \\
\hline 1 & 53.5 & 20.69 \\
\hline 2 & 59.5 & 15.82 \\
\hline 3 & 58 & 16.28 \\
\hline 4 & 56.5 & 16.21 \\
\hline 5 & 58.5 & 15.07 \\
\hline 6 & 60.5 & 15.41 \\
\hline 7 & 58 & 14.57 \\
\hline 8 & 57.5 & 16.57 \\
\hline 9 & 58 & 15.74 \\
\hline 10 & 55 & 14.27 \\
\hline 11 & 55.5 & 17.58 \\
\hline
\end{tabular}




\begin{tabular}{ccc}
\hline 12 & 52.5 & 16.86 \\
\hline 13 & 59 & 15 \\
\hline 14 & 43.5 & 17.93 \\
\hline 15 & 53 & 14.92 \\
\hline 16 & 57 & 16.72 \\
\hline 17 & 64.5 & 14.25 \\
\hline 18 & 47.5 & 16.97 \\
\hline 19 & 53 & 17.71 \\
\hline 20 & 48 & 16.12 \\
\hline
\end{tabular}

Untuk membuktikan apakah ada Hubungan power otot tungkai dengan kecepatan lari jarak pendek pada mahasiswa Pendidikan Jasmani Olahraga Kesehatan dan Rekreasi (PJKR) Fakultas Olahraga dan Kesehatan Universitas Negeri Gorontalo, perlu dilakukan pengujian hipotesis dengan menggunakan rumus product moment sebagai berikut :

$$
r_{x y}=\frac{n \sum x_{i} y_{i}-\left(\sum x_{i}\right)\left(\sum y_{i}\right)}{\sqrt{\left(n \sum x_{i}{ }^{2}-\left(\sum x_{i}\right)^{2}\right)\left(n \sum y_{i}{ }^{2}-\left(\sum y_{i}\right)^{2}\right.}}
$$

Keterangan :

$\sum \mathrm{xy} \quad=$ Koefisien korelasi antara variabel $\mathrm{x}$ dan variabel $\mathrm{y}$

$\sum_{\mathrm{x}} \quad=$ Jumlah Seluruh Variabel $\mathrm{x}$

$\sum_{\mathrm{y}} \quad=$ Jumlah Seluruh Variabel y

$\sum_{\mathrm{xy}}=$ Jumlah Perkalian antara skor $\mathrm{x}$ dan skor $\mathrm{y}$

$\mathrm{N} \quad=$ Jumlah Sampel

$\sum \quad=\operatorname{Jumlah}($ Sigma $)$

Adapun data koefisien hubungan antara variabel $\mathrm{X}$ dengan variabel $\mathrm{Y}$ pada mahasiswa Pendidikan Jasmani Olahraga Kesehatan Dan Rekreasi (PJKR) Fakultas Olahraga dan Kesehatan Universitas Negeri Gorontalo, dapat dilihat pada tabel berikut:

Tabel 2, Hubungan Antara Variabel X Dengan Variabel Y

\begin{tabular}{rrrrrc}
\hline No & \multicolumn{1}{c}{ X } & \multicolumn{1}{c}{$y$} & \multicolumn{1}{c}{ x2 } & \multicolumn{1}{c}{ y2 } & \multicolumn{1}{c}{ xy } \\
\hline 1 & 53.5 & 79.3421 & 2862.25 & 6295.1 & 4244.802 \\
\hline 2 & 59.5 & 47.3026 & 3540.25 & 2237.5 & 2814.506 \\
\hline 3 & 58 & 50.3289 & 3364 & 2533 & 2919.078 \\
\hline 4 & 56.5 & 49.8684 & 3192.25 & 2486.8 & 2817.565 \\
\hline 5 & 58.5 & 42.3684 & 3422.25 & 1795.0 & 2478.552 \\
\hline 6 & 60.5 & 44.6053 & 3660.25 & 1989.6 & 2698.618 \\
\hline 7 & 58 & 39.0789 & 3364 & 1527.1 & 2266.578 \\
\hline
\end{tabular}




\begin{tabular}{rrrrrr}
\hline 8 & 57.5 & 52.2368 & 3306.25 & 2728.6 & 3003.618 \\
\hline 9 & 58 & 46.7763 & 3364 & 2188.0 & 2713.026 \\
\hline 10 & 55 & 37.1053 & 3025 & 1376.8 & 2040.789 \\
\hline 11 & 55.5 & 58.8816 & 3080.25 & 3467.0 & 3267.927 \\
\hline 12 & 52.5 & 54.1447 & 2756.25 & 2931.6 & 2842.598 \\
\hline 13 & 59 & 41.9079 & 3481 & 1756.2 & 2472.565 \\
\hline 14 & 43.5 & 61.1842 & 1892.25 & 3743.5 & 2661.513 \\
\hline 15 & 53 & 41.3816 & 2809 & 1712.4 & 2193.223 \\
\hline 16 & 57 & 53.2237 & 3249 & 2832.7 & 3033.75 \\
\hline 17 & 64.5 & 36.9737 & 4160.25 & 1367.0 & 2384.802 \\
\hline 18 & 47.5 & 54.8684 & 2256.25 & 3010.5 & 2606.25 \\
\hline 19 & 53 & 59.7368 & 2809 & 3568.4 & 3166.052 \\
\hline 20 & 48 & 49.2763 & 2304 & 2428.1 & 2365.263 \\
\hline Jumlah 1108.5 & 1000.59 & 61897.75 & 51975.9 & 54991.08 \\
\hline
\end{tabular}

Dengan melihat tabel kerja korelasi dengan jumlah responden 20 mahasiswa maka diperoleh harga kritik $\mathrm{r}$ product moment pada taraf signifikan $5 \%$ adalah 0.444 , maka dapat diketahui :

$\mathrm{N}=20$

$\sum_{\mathrm{x}} \quad=1108.5$

$\sum_{\mathrm{y}} \quad=1000.59$

$\sum_{\mathrm{x}^{2}}=61897.75$

$\sum_{y^{2}}=51975.9$

$\sum_{\mathrm{xy}}=54991.08$

\section{Pembahasan}

Penelitian ini bertujuan untuk mengetahui hubungan antara power otot tungkai dengan kecepatan lari jarak pendek pada mahasiswa Pendidikan Jasmani, Kesehatan dan Rekreasi Fakultas Olahraga dan Kesehatan Universitas Negeri Gorontalo. Data menunjukkan $\mathrm{r}_{\text {hitung }}$ (2.544) $>r_{\text {tabel }}(0.444)$. Hubungan antar variabel adalah signifikan. Hal ini senada dengan penelitian yang menyatakan bahwa dengan memiliki power otot tungkai yang baik, maka kecepatan lari seseorang juga akan baik pula (Haryanto \& Fataha, 2021).

Kecepatan lari jarak pendek merupakan usaha untuk lari secepat mungkin guna mencapai kecepatan maksimal dengan waktu yang sesingkat-singkatnya (Sartono, 2018). Seperti halnya olahraga pada umumnya, lari jarak pendek memiliki beberapa aturan perlombaan yang harus dipatuhi oleh setiap pelari (Manalu, 2017). Untuk mendapatkan kecepatan tidaklah mudah, karena banyak faktor-faktor pendukung untuk memperoleh kecepatan maksimum dari seorang pelari. Gerakan lari jarak pendek menggunakan ujung-ujung kaki untuk menapak, sedangkan tumit tidak menyentuh tanah pada permulaan dari tolakan kaki sampai garis finish, dan berat 
badan pelari harus selalu berada di depan kaki pada waktu menapak atau dalam posisi badan condong ke depan.

\section{Kesimpulan}

Berdasarkan hasil analisis menunjukkan ada Hubungan Antara power Otot Tungkai Dengan Kecepatan Lari Jarak Pendek Pada Mahasiswa Pendidikan Jasmani, Kesehatan dan Rekreasi Fakultas Olahraga dan Kesehatan Universitas Negeri Gorontalo. Power otot tungkai memiliki peranan dalam menentukan kecepatan lari jarak pendek.

\section{Referensi}

Bahagia, Y. (2012). Pembelajaran Atletik. Pembelajaran Atletik, Departemen Pendidikan Nasional.

Dwi, D. D. D. (2020). Peningkatan Pembelajaran Lari Jarak Pendek Melalui Pendekatan Bermain Lari Bola Keranjang Pada Siswa Sekolah Dasar. Jurnal Master Penjas \& Olahraga, 1(2). https://doi.org/10.37742/jmpo.v1i2.13

Faizah, A., \& Herdyanto, Y. (2019). Analisis Gerak Akselerasi Sprint 100 Meter (Studi Pada Atlet Lari Sprint 100 Meter Putra Pelatnas B, Ditinjau Dari Aspek Biomekanika). Jurnal Prestasi Olahraga, 1(1).

Gunadi, D., \& Kuncoro, B. (2020). Implementasi Penerapan Model Latihan Progresif Pada Klub Atletik ADIOS UTP Surakarta. BERNAS: Jurnal Pengabdian Kepada Masyarakat, 1(3). https://doi.org/10.31949/jb.v1i3.298

Hardinoto, N., Syah, S., \& Sitepu, I. D. (2017). Perbedaan Karakter Olahraga Kompetitif. Jurnal Prestasi.

Haryanto, A. I., \& Fataha, I. (2021). Korelasi Panjang Tungkai, Power Otot Tungkai Dan Kecepatan Lari Dengan Hasil Lompat Jauh. Jambura Health and Sport Journal, 3(1). https://doi.org/10.37311/jhsj.v3i1.9890

Henjilito, R. (2017). Pengaruh Daya Ledak Otot Tungkai, Kecepatan Reaksi dan Motivasi terhadap Kecepatan Lari Jarak Pendek 100 Meter pada Atlet PPLP Provinsi Riau. Journal Sport Area. https://doi.org/10.25299/sportarea.2017.vol2(1).595

Iskandar, H. (2017). Sehat-Bugar untuk Tua-Muda (Atletik Jalan dan Lari) (Issue Kementerian Pendidikan dan Kebudayaan).

Ismadraga, A., \& Lumintuarso, R. (2015). Pengembangan Model Latihan Kribo Untuk Power Tungkai Atlet Lompat Jauh dan Sprinter SKO SMP. Jurnal Keolahragaan. https://doi.org/10.21831/jk.v3i1.4966

Jarver, J. (2014). Belajar dan Berlatih Atletik. Pionir Jaya.

Kuswahyudi, K., \& Nurdin, F. (2017). Hubungan Bentuk Telapak Kaki Panjang Tungkai dengan Daya Ledak Otot Tungkai terhadap Atlet Kids Athletics Putri 11-14 Tahun. SEGAR. https://doi.org/10.21009/segar.0502.05

Manalu, W. (2017). Pengaruh Metode Pembelajaran Dan Motivasi Belajar Terhadap Hasil 
Belajar Lari Cepat. JURNAL PENDIDIKAN JASMANI DAN OLAHRAGA, 2(2). https://doi.org/10.17509/jpjo.v2i2.8179

Mirhan, J. (2016). Hubungan Antara Percaya Diri dan Kerja Keras dalam Olahraga dan Keterampilan Hidup. Jurnal Olahraga Prestasi, 12(1). https://doi.org/10.21831/jorpres.v12i1.9499

Muller, H., \& Ritzdorf, W. (2000). Pedoman Mengajar Atletik Lari! Lempar! Lompat! (S. Danusyogo (ed.); Level I). IAAF-RDC.

Pembayun, D. L., Wiriawan, O., \& Setijono, H. (2018). Pengaruh Latihan Jump To Box, Depth Jump dan Single Leg Depth Jump Terhadap Peningkatan Kekuatan Otot Tungkai dan Power Otot Tungkai. Jurnal SPORTIF: Jurnal Penelitian Pembelajaran. https://doi.org/10.29407/js_unpgri.v4i1.12006

Putra, M. F. P., \& Ita, S. (2019). Gambaran kapasitas fisik atlet Papua: Kajian menuju PON XX Papua. Jurnal Keolahragaan, 7(2). https://doi.org/10.21831/jk.v7i2.26967

Ramadhan, M. G., Ma'mun, A., \& Mahendra, A. (2020). Implementasi Kebijakan Olahraga Pendidikan sebagai Upaya Pembangunan Melalui Olahraga Berdasarkan Undang-Undang Sistem Keolahragaan Nasional. Jurnal Terapan Ilmu Keolahragaan, 5(1). https://doi.org/10.17509/jtikor.v5i1.23824

Sartono, S. (2018). Pengaruh Latihan Double Leg Speed Hop dan Double Leg Box Bound terhadap Kecepatan Lari 100 Meter. JUARA: Jurnal Olahraga. https://doi.org/10.33222/juara.v3i1.215

Widiastuti, W., \& Pratiwi, E. (2017). Meningkatkan Hasil Belajar Gerak Dasar Lari Jarak Pendek Melalui Pendekatan Bermain. GLADI JURNAL ILMU KEOLAHRAGAAN, 8(1). https://doi.org/10.21009/gjik.081.04 